\title{
Pengaruh Penguasaan Teori Pengkajian Puisi dan Motivasi Belajar Terhadap Kemampuan Menulis Puisi Pada Siswa Kelas IX SMP Negeri 36 Palembang
}

\section{Oleh}

\section{Liana}

Guru SMP Negeri 36 Palembang

Emotluhun21@yahoo.com

Abstract: The purpose of this study was to determine whether there is the influence of mastering the theory study of poetry, the motivation of the ability to write poetry. The hypotheses are: (1) there is significant relationship between motivation to learn and the ability to write poetry, (2) there is a significant relationship between mastery of the theory of poetry and the ability to write poetry, (3) there is a significant relationship between having motivation to learn, mastery of the theory of poetry the ability to write poetry. The study population was $9^{\text {th }}$ grade students of SMP Negeri 12 Palembang.1. These samples included 40 students. Instrument of this study was a form of objective tests, written tests and questionnaires. The results of this study indicated that there is significant influence between having motivation to learn, mastery of the theory of poetry on the ability to write poetry. The influence was $96.5 \%$.

Keywords: having motivation to learn, mastery of the theory of poetry, writing poetry.

\section{PENDAHULUAN}

Memahami sastra adalah kegiatan menggauli cipta sastra dengan sungguhsungguh hingga tumbuh pengertian, penghargaan, kepekaan pikiran kritis, dan kepekaan perasaan yang baik terhadap cipta sastra (Efendi, 2004:6). Untuk itu, pembelajaran apresiasi sastra harus diarahkan pada proses pencapaian tujuan memahami.

Pembelajaran memahami sastra bertujuan agar siswa mampu memahami, menikmati, dan memanfaatkan karya sastra guna mengembangkan kepribadian, memperluas wawasan kehidupan, meningkatkan pengetahuan, dan kemampuan berbahasa (Depdiknas, 2004). Pembelajaran sastra ditekankan pada upaya peningkatan kemampuan siswa dalam memahami karya sastra. Sastra merupakan pembayangan atau pelukisan kehidupan dan pikiran imajinasi ke dalam bentuk-bentuk dan struktur bahasa.

Dalam kegiatan memahami puisi diharapkan siswa mengalami langsung dan secara nyata berhubungan dengan karya puisi, mereka mempergunakan daya nalar dan kemampuan memahami puisi secara mendalam, meluas, dan berwawasan. Hal ini berarti, siswa sudah belajar karya sastra puisi secara nyata atau sesuai dengan kehidupannya. Dengan demikian, mereka memperoleh pengalaman menghayati, dan menikmati puisi tersebut sehingga pembelajaran memahami tidak verbalisme. Selain itu, pembelajaran memahami puisi juga bertujuan untuk meningkatkan kepekaan berpikir kritis siswa. Dengan menggunakan strategi pembelajaran yang tepat, motivasi 
belajar siswa dapat bangkit. Siswa menjadi antusias dalam belajar, sehingga tujuan pembelajaran apresiasi puisi dapat tercapai. Namun, dalam kenyataannya pembelajaran memahami puisi belum optimal.

Berdasarkan hasil di kelas IX SMP Negeri 36 Palembang diperoleh keterangan bahwa puisi kurang diminati dan kurang mendapat respons yang baik dari siswa. Ketika guru mengajarkan puisi, siswa tidak langsung mengikuti pembelajaran secara antusias. Siswa tidak memberikan respons secara cepat. Salah satu penyebab siswa kurang antusias terhadap pembelajaran puisi, strategi yang digunakan guru cenderung berorientasi kepada hasil (result oriented) daripada proses (process oriented). Hal ini mengakibatkan pelajaran sastra yang disajikan tidak menarik dan menyenangkan dan kurang diarahkan pada kreativitas sastra peserta didik. Guru dalam pembelajaran puisi hanya menugaskan peserta didik menjawab pertanyaan yang ada dalam buku atau LKS. Akibatnya, pengalaman belajar yang diberikan kepada siswa menjadi kurang optimal. Guru hanya menjelaskan struktur fisik dan struktur batin puisi. Struktur fisik tersebut ialah rima, diksi, citraan, gaya bahasa, dan struktur batin berupa tema, nada, perasaan dan amanat. Guru tidak memberikan kesempatan siswa untuk merespons isi puisi yang dianalisis berdasarkan pengalamannya, oleh sebab itu siswa tidak dapat memahami puisi secarah utuh dan menyeluruh.

Salah satu kegiatan produktif adalah menulis karya sastra. Kegiatan ini memberikan banyak manfaat bagi kehidupan. Hal itu sesuai dengan pernyataan Taufik Ismail bahwa sastra adalah karya cipta dan rasa. Kegiatan kreatif ini juga bisa menjadi sarana pembentukan karakter suatu bangsa yang beradab (Ismail, 2011: 1).

$$
\text { Rahmanto }
$$

mengemukakan bahwa pengajaran sastra dapat membantu pendidikan secara utuh apabila cakupannya meliputi empat manfaat, yaitu (1) membantu keterampilan berbahasa, (2) meningkatkan pengetahuan budaya, (3) pengembangan cipta dan rasa, (4) dan menunjang pembentukan watak.

$$
\text { Salah satu cara untuk }
$$
mengembangkan apresiasi sastra pada peserta didik ialah dengan pengajaran puisi. Tujuan pengajaran puisi di sekolah adalah agar peserta didik memperoleh kesadaran yang lebih terhadap dirinya sendiri, orang lain dan lingkungan sekitar, memperoleh kesenangan, dan peserta didik memperoleh pengetahuan dan pengertian dasar tentang puisi. Yang perlu mendapat perhatian dalam pengajaran puisi di sekolah adalah pemilihan bahan pengajaran dan penyajiannya.

Sesuai dengan standar kompetensi dalam Kurikulum Tingkat Satuan Pendidikan (KTSP), di dalam belajar bahasa 
keterampilan berbahasa yang diberikan kepada siswa yang meliputi empat aspek, yakni: mendengar, berbicara, membaca, dan menulis dengan ragam sastra.

Dalam kegiatan berbahasa, menulis merupakan kemampuan berbahasa yang sama pentingnya dengan tiga kemampuan berbahasa yang lain, yaitu mendengarkan, membaca, dan berbicara. Dalam menulis dan mengarang siswa dituntut untuk mampu menyatakan kepada orang lain tentang apa yang dirasakan, dikehendaki dan dipikirkan dengan memakai bahasa tulisan.

Keterampilan menulis, perlu dimiliki oleh setiap orang untuk mengembangkan bakat pribadi seseorang melalui sebuah tulisan. Berlatih menulis merupakan modal utama untuk menggali potensi dalam mengungkapkan ide atau gagasan. Oleh sebab itu, keterampilan menulis merupakan keterampilan berbahasa yang harus diutamakan karena, tanpa menulis apalah arti ilmu pengetahuan yang kita miliki, kalau tidak bisa kita tuangkan ke dalam sebuah tulisan.

\section{METODE PENELITIAN}

Metode yang digunakan dalam penelitian ini adalah metode sebab akibat (causal effect). Menurut Sugiyono (2008:224), metode sebab akibat adalah metode yang digunakan untuk mencari besarnya sumbangsi (kontribusi) yang ditunjukkan oleh variabel $\mathrm{X} 1$ dan $\mathrm{X} 2$ terhadap Y seperti tersaji dalam Tabel 3.1 berikut.

TABEL 3.1

\section{DESAIN PENELITIAN}

\begin{tabular}{|c|c|c|}
\hline $\begin{array}{c}\text { Faktor yang dipengaruhi } \\
\text { (variabel terikat) }\end{array}$ & \multicolumn{2}{|c|}{$\begin{array}{c}\text { Faktor yang berpengaruh } \\
\text { (variabel bebas }\end{array}$} \\
\hline $\begin{array}{c}\text { Kemampuan Menulis Puisi } \\
\text { (Y) }\end{array}$ & $\begin{array}{c}\text { Penguasaan } \\
\text { Teori Puisi } \\
\text { (X1) }\end{array}$ & $\begin{array}{c}\text { Motivasi Belajar } \\
\text { (X2) }\end{array}$ \\
\hline
\end{tabular}

\section{TEKNIK PENGUMPULAN DATA}

Pengumpulan data dalam penelitian ini, terutama yang berkenaan dengan penguasaan teori pengkajian puisi, dan kemampuan menulis puisi dilakukan dengan teknik tes. Untuk variabel motivasi belajar 
siswa dipakai teknik nontes (dalam hal ini adalah angket). Penguasaan teori pengkajian puisi digunakan bentuk tes objektif, sedangkan untuk variabel kemampuan menulis puisi digunakan tes subjektif (esai).

Dalam penelitian ini, instrumen yang digunakan untuk mengumpulkan data adalah angket dan tes. Tes digunakan untuk mengumpulkan data variabel bebas pertama $\left(\mathrm{X}_{1}\right)$, yaitu: penguasaan teori pengkajian puisi, sedangkan angket digunakan untuk mengumpulkan data variabel bebas kedua $\left(\mathrm{X}_{2}\right)$, yaitu motivasi belajar. Teknik pengumpulan data untuk variabel kemampuan menulis mengunakan tes esai, penulis memberikan tes pada siswa, yakni menulis puisi dengan tiga alternatif pilihan melalui objek gambar, yakni tema keindahan alam, tema bencana alam dan tema hutan gundul yang terdiri dari minimal 3 bait dengan waktu keseluruhan 60 menit. Komponen-komponen yang dinilai dalam menulis puisi: (1), tema. (2), Amanat. (3) rasa. (4), nada. Skor maksimum untuk masing-masing komponen mengacu pada pendapat Suherman (kutip Muslim, 2009:97) seperti berikut: (a) tema $=35$; (b) amanat $=$ 30 ; (c) rasa $=25$; (4) nada $=10$. Jadi skor maksimum keseluruhan 100 .

\section{TEKNIK ANALISIS DATA}

Data penelitian di analisis dengan menggunakan teknik analisis data statistik deskriptif dan inferensial. Teknik analisis data secara deskriptif digunakan untuk memperoleh gambaran karakteristik penyebaran nilai setiap variabel yang diteliti. Penyajian data meliputi nilai range, nilai terendah, nilai tertinggi, rerata, simpangan baku, dan varian. Sedangkan, analisis inferensial digunakan untuk menguji hipotesis dengan menggunakan regresi linier sederhana dan regresi ganda. Namun sebelum dilakukan tes analisis inferensial terlebih dahulu dilakukan tes uji prasyarat analisis, yaitu uji normalitas dan homogenitas.

\section{HASIL DAN PEMBAHASAN}

Bab ini menguraikan hasil analisis data dan pembahasan tentang pengaruh penguasaan teori pengkajian puisi dan motivasi belajar terhadap kemampuan menulis puisi pada siswa kelas IX SMP Negeri 36 Palembang. Dalam pengolahan data hasil penelitian, uji prasyarat analisis

diperlukan untuk memastikan bahwa data yang dihasilkan sahih dan dapat dipercaya. Kepercayaan hasil penelitian mengacu pada uji prasyarat analisis yang dilakukan. Oleh karena itu, peneliti menguji kenormalan dan homogenitas data.

Secara berurutan, bab ini mendeskripsikan dan menganalisis data serta menginterpretasikan hasil pengujian hipotesis. Pengolahan data hasil penelitian 
diperoleh dari temuan data di lapangan yang

meliputi data (1) Penguasaan teori

pengkajian puisi (2) Kemampuan menulis puisi, (3) Motivasi belajar.

Setelah melakukan pengujian analisis normalitas, selanjutnya peneliti melakukan uji homogenitas varibel penguasaan teori penkajian puisi dan kemampuan menulis puisi terhadap motivasi belajar sebagai faktornya yang berguna untuk mengetahui apakah skor hasil tes $(\mathrm{X} 1, \mathrm{X} 2, \mathrm{Y})$ memiliki varian sama atau tidak. Skor hasil tes dikatakan mempunyai variasi yang sama apabila nilai probabilitas (signifikansi) nya lebih dari 0,05 atau apabila P-value dari hasil perhitungan lebih besar dari $=0,05$, atau dapat juga dilihat dari angka Levene Statistic menunjukkan, apabila nilainya semakin kecil, maka semakin besar homogenitasnya. Pengujian homogenitas secara lengkap dapat dilihat pada Tabel 4.3 berikut.

\section{TABEL 4.3}

HASIL HOMOGENITAS DATA PENELITIAN

\begin{tabular}{|c|c|c|c|c|c|}
\hline \multicolumn{7}{|c|}{ Test of Homogeneity of Variances } \\
\hline Variabel & $\begin{array}{c}\text { Levene } \\
\text { Statistic }\end{array}$ & df1 & df2 & Sig. & Keterangan \\
\hline $\begin{array}{c}\text { kemampuan menulis } \\
\text { puisi }\end{array}$ & 2.102 & 2 & 37 & $\mathbf{0 . 1 3 7}$ & Homogen \\
\hline $\begin{array}{c}\text { penguasaan teori } \\
\text { pengkajian puisi }\end{array}$ & 2.056 & 2 & 37 & $\mathbf{0 . 1 4 2}$ & Homogen \\
\hline
\end{tabular}

Berdasarkan data pada Tabel

$4.3 \mathrm{di}$ atas, nilai probabilitas (signifikan) penguasaan teori pengkajian puisi adalah sebesar 0.142 dan nilai probabilitas (signifikan) variabel kemampuan menulis puisi adalah sebesar 0.137. Dengan demikian, variabel penguasaan teori pengkajian puisi dan kemampuan menulis puisi dapat dikatakan memiliki variansi yang sama atau homogen karena nilai probabilitasnya lebih dari 0.05 .
Dalam menguji normalitas, peneliti menggunakan bantuan program Statical Product and Service Solutions (SPSS). Menurut Priyatno (2008:30) suatu data dapat dikategorikan normal, jika nilai signifikansi atau probabilitas variabel lebih besar dari $(>)$ 0,05. Sebaliknya, jika nilai probabilitasnya lebih kecil dari $(<)$ 0,05, maka data tersebut tidak berdistribusi normal. Pengujian normalitas data secara lengkap dapat dilihat pada Tabel 4.2 berikut. 


\section{PENGUJIAN HIPOTESIS}

TABEL 4.2

HASIL UJI NORMALITAS VARIABEL X1, X2 DAN Y

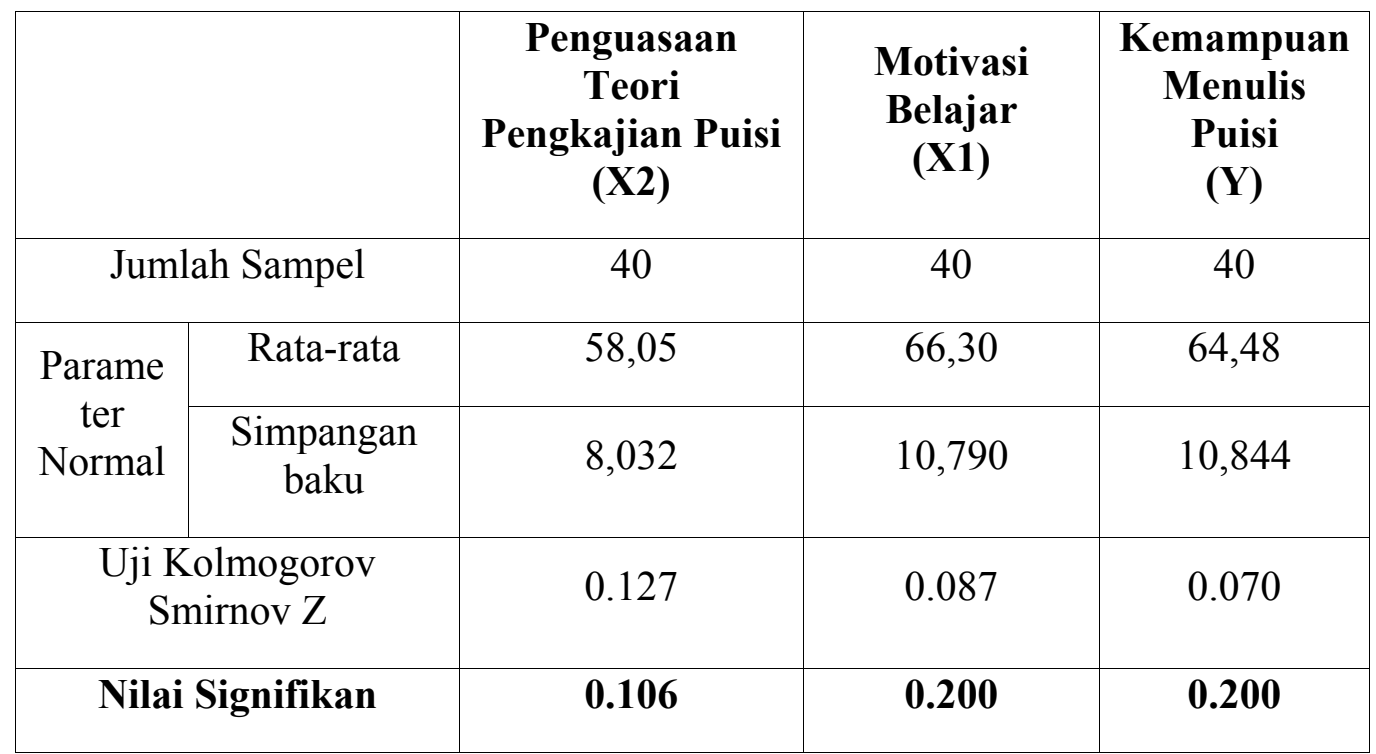

Berdasarkan Tabel 4.2 hasil pengujian di atas, diketahui bahwa nilai signifikan untuk skor tes penguasaan teori pengkajian puisi adalah 0.106, nilai signifikan untuk skor motivasi belajar adalah 0.200 , dan nilai signifikan untuk skor tes kemampuan menulis puisi adalah 0.200. Dengan demikian semua variabel $\mathrm{X} 1, \mathrm{X} 2$, dan Y terdistribusi secara normal karena nilai signifikansi atau probabilitas variabel lebih besar dari $(>) 0,05$.

\section{A. HIPOTESIS PERTAMA}

Penguasaan teori pengkajian puisi terhadap kemampuan siswa menulis puisi dapat dilihat pada tabel berikut.

TABEL 4.7

KONTRIBUSI PENGUASAAN TEORI PENGKAJIAN PUISI TERHADAP KEMAMPUAN MENULIS PUISI

\begin{tabular}{|c|c|c|c|c|c|c|}
\hline \multicolumn{7}{|c|}{ Coefficients $^{\mathrm{a}}$} \\
\hline & & \multicolumn{2}{|c|}{$\begin{array}{l}\text { Unstandardized } \\
\text { Coefficients }\end{array}$} & \multirow{2}{*}{\begin{tabular}{c|}
$\begin{array}{c}\text { Standardize } \\
\mathrm{d} \\
\text { Coefficients }\end{array}$ \\
Beta
\end{tabular}} & \multirow[b]{2}{*}{$\mathrm{t}$} & \multirow[b]{2}{*}{ Sig. } \\
\hline \multicolumn{2}{|c|}{ Model } & $\mathrm{B}$ & Std. Error & & & \\
\hline \multirow[t]{3}{*}{1} & (Constant) & 64.340 & 11.991 & & 5.366 & 0.000 \\
\hline & $\begin{array}{l}\text { Penguasaan teori } \\
\text { pengkajian puisi }\end{array}$ & 0.014 & 0.155 & 0.014 & 0.092 & 0.927 \\
\hline & motivasi belajar & 5.907 & 1.782 & 0.515 & 3.316 & 0.002 \\
\hline
\end{tabular}


Berdasarkan hasil analisis data melalui pengujian hipotesis di atas, mengidikasikan bahwa (1) hipotesis pertama, yakni penguasaan teori pengkajian puisi (X1) terhadap kemampuan menulis puisi (Y) tidak berkontribusi secara signifikan terhadap kemampuan menulis puisi karena diperoleh nilai signifikan koefisien kontribusi penguasaan teori pengkajian puisi (X1) terhadap kemampuan menulis puisi (Y) adalah 0.927 , lebih besar dari nilai signifikan 0.05 .

\section{B. HIPOTESIS KEDUA}

Motivasi belajar terhadap kemampuan siswa menulis puisi dapat dilihat pada tabel berikut.

\section{TABEL 4.8 \\ KONTRIBUSI MOTIVASI BELAJAR TERHADAP KEMAMPUAN MENULIS PUISI}

\begin{tabular}{|c|c|c|c|c|c|c|}
\hline \multicolumn{7}{|c|}{ Coefficients $^{\mathrm{a}}$} \\
\hline \multirow{2}{*}{\multicolumn{2}{|c|}{ Model }} & \multicolumn{2}{|c|}{$\begin{array}{l}\text { Unstandardized } \\
\text { Coefficients }\end{array}$} & \multirow{2}{*}{$\begin{array}{c}\text { Standardized } \\
\text { Coefficients } \\
\text { Beta }\end{array}$} & \multirow[b]{2}{*}{$\mathrm{t}$} & \multirow[b]{2}{*}{ Sig. } \\
\hline & & $\mathrm{B}$ & Std. Error & & & \\
\hline \multirow[t]{3}{*}{1} & (Constant) & 64.340 & 11.991 & & 5.366 & 0.000 \\
\hline & $\begin{array}{l}\text { Penguasaan teori } \\
\text { pengkajian puisi }\end{array}$ & 0.014 & 0.155 & 0.014 & 0.092 & 0.927 \\
\hline & motivasi belajar & 5.907 & 1.782 & 0.515 & 3.316 & 0.002 \\
\hline
\end{tabular}

a. Dependent Variable: kemampuan menulis puisi

Berdasarkan hasil analisis data melalui pengujian hipotesis di atas, mengidikasikan bahwa motivasi belajar berkontribusi secara signifikan terhadap kemampuan menulis puisi karena diperoleh nilai signifikan koefisien kontribusi motivasi belajar (X2) dan kemampuan menulis puisi (Y) adalah 0.002 , lebih kecil dari nilai signifikan 0.05 .

\section{HIPOTESIS KETIGA}

Motivasi belajar terhadap kemampuan siswa menulis puisi dapat dilihat pada tabel berikut

TABEL 4.9

KONTRIBUSI PENGUASAAN TEORI PENGKAJIAN PUISI DAN MOTIVASI BELAJAR SISWA TERHADAP KEMAMPUAN MENULIS PUISI

\begin{tabular}{|c|c|c|c|c|c|c|}
\hline \multicolumn{7}{|c|}{ ANOVA $^{b}$} \\
\hline \multicolumn{2}{|c|}{ Model } & $\begin{array}{l}\text { Sum of } \\
\text { Squares }\end{array}$ & $\mathrm{df}$ & Mean Square & $\mathrm{F}$ & Sig. \\
\hline \multirow[t]{3}{*}{1} & Regression & 762.587 & 2 & 381.293 & 6.888 & $\mathbf{0 . 0 0 3}^{\mathrm{a}}$ \\
\hline & Residual & 2048.257 & 37 & 55.358 & & \\
\hline & Total & 2810.844 & 39 & & & \\
\hline \multicolumn{7}{|c|}{ a. Predictors: (Constant), motivasi belajar, motivasi belajar } \\
\hline \multicolumn{7}{|c|}{ b. Dependent Variable: kemampuan menulis puisi } \\
\hline
\end{tabular}


Berdasarkan hasil analisis data melalui pengujian hipotesis di atas, mengidikasikan bahwa penguasaan teori pengkajian puisi dan motivasi belajar berkontribusi secara simultan dan signifikan terhadap kemampuan menulis puisi karena diperoleh nilai signifikan koefisien kontribusi penguasaan teori pengkajian puisi (X1) dan motivasi belajar secara simultan terhadap kemampuan menulis puisi (Y) adalah 0.003, lebih kecil dari nilai signifikan 0.05 .

Selain itu, juga diperoleh besarnya kontribusi penguasaan teori pengkajian puisi dan motivasi belajar secara simultan mempengaruhi kemampuan menulis puisi secara langsung adalah $27.10 \%$. dan sisanya $81.90 \%$ dipengaruhi oleh faktor-faktor lain yang tidak dijelaskan dalam penelitian ini. Hal ini dibuktikan oleh nilai $\mathrm{R}$ square, yakni 0.271 .

\section{SIMPULAN}

Berdasrkan hasil penelitian, analisis data, dapat disimpulkan sebagai berikut ini.

Penguasaan teori pengkajian puisi (X1) terhadap kemampuan menulis puisi (Y) tidak berkontribusi secara signifikan terhadap kemampuan menulis puisi karena diperoleh nilai signifikan koefisien kontribusi penguasaan teori puisi (X1) terhadap kemampuan menulis puisi (Y) adalah 0.927, lebih besar dari nilai signifikan 0.05. Dengan kata lain bertambahnya penguasaan teori pengkajian puisi, belum tentu menyebabkan peningkatan dan pengetahuan siswa tentang puisi dan kemampuan siswa dalam menulis puisi.

$\begin{array}{cccc} & \text { Motivasi } & \text { belajar berkontribusi } \\ \text { secara } & \text { signifikan terhadap kemampuan }\end{array}$
menulis puisi karena diperoleh nilai signifikan koefisien kontribusi motivasi belajar (X2) dan kemampuan menulis puisi (Y) adalah 0.002, lebih kecil dari nilai signifikan 0.05. Dengan kata lain bertambahnya motivasi belajar dapat menyebabkan peningkatan dan pengetahuan siswa tentang penguasaan teori pengkajian puisi dan kemampuan menulis puisi.

Penguasaan teori pengkajian puisi dan motivasi belajar berkontribusi secara simultan dan signifikan terhadap kemampuan menulis puisi karena diperoleh nilai signifikan koefisien kontribusi penguasaan teori pengkajian puisi (X1) dan motivasi belajar secara simultan terhadap kemampuan menulis puisi (Y) adalah 0.003 , lebih kecil dari nilai signifikan 0.05 . Dengan kata lain makin tinggi motivasi belajar dan penguasaan teori pengkajian puisi secara bersama-sama dan signifikan dapat meningkatkan kemampuan menulis puisi. 
Berdasarkan temuan tersebut, dapat disimpulkan bahwa terdapat penguasaan teori pengkajian puisi dan motivasi belajar secara bersama-sama dan signifikan dapat mempengaruhi kemampuan menulis puisi.

\section{DAFTAR PUSTAKA}

Arikunto, Suharsimi. 2005. Manajemen Penelitian. Jakarta: PT Asdi Mahasatya.

Arikunto. Suharsini. 2010. Prosedur Penelitian: Suatu Pendekatan Praktik. Jakarta: PT Rinneka Cipta.

Aminuddin. 2002. Pengantar Apresiasi Karya Sastra. Bandung: Sinar Baru Algesindo.

Borich, G and Kubiszyn, T. 1993. Education Testing and Measurement: Classroom Application and Practice. (4 ${ }^{\text {th }}$ ed.). NewYork: Harper Collin College Publisher.
Djajadisastra, Jusuf. 1996. Teori Sastra. Bandung: PPPG Tertulis

Esten Mursal. 1990. Kesusastraan, Pengantar Teori dan Sejarah. Bandung: Angkasa.

Fraenkel, Jack $\mathrm{R}$ and Norman E Wallen.1990. How to Design and Evaluate Research. New York, NY : MC. Gray- Hill. Inc.

Gusnetti. 1997. Hubungan Keterampilan Membaca dan Motivasi Belajar Terhadap Keterampilan Menulis karangan pada siswa SMA Muhammadiyah Padang. Tesis tidak Diterbitkan.

Hadi, Manuri. 2009. Peningkatan Kemampuan Menulis Puisi pada Siswa Kelas V SDN Teguhan 2 Kecamatan Paron Melalui Penerapan Model Pembelajaran Berbasis Masalah. Tesis tidak Diterbitkan. Surakarta. 